\title{
Bilen Language
}

National Cancer Institute

\section{Source}

National Cancer Institute. Bilen Language. NCI Thesaurus. Code C153870.

An Afro-Asiatic language spoken by the Bilen people in Eritrea and eastern Sudan. 